\title{
Pengaruh Kepemimpinan Transformasional, Lingkungan Kerja Fisik Dan Stres Kerja Terhadap Kinerja Pegawai Pada Kantor Kecamatan Penjaringan Jakarta Utara
}

\author{
Mochamad Soelton dan Dian Yasinta \\ Facultas Ekonomi dan Bisnis Universitas Mercu Buana \\ E-mail:soelton@mercubuana.ac.id dandianyasinta11@gmail.com
}

\begin{abstract}
This research aims to know the influence of transformational leadership, physical work environment and work stress employee performance in Kantor Kecamatan Penjaringan North Jakarta. The object for this research is employee at Kantor Kecamatan Penjaringan North Jakarta. This research was done to 70 respondents by using quantitative descriptive approach. This data analysis which is used is statistic analysis in the form of double linear regression test. The results of this study indicate that partially and simultaneously variable transformational leadership, physical work environment simultaneously have a positive and significant effect on employee performance, job stress has a negative but not significant effect on employee performance on Kantor Kecamatan Penjaringan North Jakarta. It has been the result of (t) patial shows significant pont of three independent variables that supports hipothesy. Therefore the test results of this study states that there is a simultaneous influence between transformational leadership variables, physical work environment and job stress on employee performance at Kantor Kecamatan Penjaringan North Jakarta.
\end{abstract}

Keywords: transformational leadership, physical work environment, and work stress employee performance

Abstrak: Penelitian ini untuk mengetahui pengaruh kepemimpinan transformasional, lingkungan kerja fisik dan stres kerja terhadap kinerja pegawai pada Kantor Kecamatan Penjaringan Jakarta Utara. Objek penelitian ini adalah pegawai dan SATPOL PP yang bekerja di Kantor Kecamatan Penjaringan Jakarta Utara.Penelitian ini dilakukan 70 responden dengan menggunakan pendekatan deskriptif kuantitatif.Karena itu analisis data yang digunakan adalah analisis statistik dalam bentuk uji regresi linear berganda.Hasil penelitian ini menunjukkan bahwa secara parsial dan simultan variabel kepemimpinan transformasional, lingkungan kerja fisik secara simultan berpengaruh positif dan signifikan terhadap kinerja pegawai, stres kerja berpengaruh negatif tapi tidak signifikan terhadap kinerja pegawai pada Kantor Kecamatan Penjaringan Jakarta Utara.Hal ini dibuktikan dari hasil uji parsial (uji t) juga menunjukkan nilai signifikan dari tiga variabel bebas yang mendukung hipotesis.Oleh karena itu hasil uji dari penelitian ini menyatakan bahwa terdapat pengaruh secara simultan antara variabel kepemimpinan transformasional, lingkungan kerja fisik dan stres kerja terhadap kinerja pegawai Kantor Kecamatan Penjaringan Jakarta Utara.

Kata kunci: kepemimpinan transformasional, lingkungan kerja fisik, dan stres kerja, kinerja pegawai 


\section{PENDAHULUAN}

Bagi setiap organisasi peranan anggota organisasi yang bersangkutan sangatlah membantu terhadap terselenggaranya proses pencapaian tujuan. Dalam usaha tersebut organisasi harus memiliki orang-orang yang ditetapkan organisasi.Hal ini berarti kelangsungan suatu organisasi sangat ditentukan oleh faktor manusia sebagai suatu sumber daya yang potensial.Masjaya (2013).

Sehubungan dengan itu, peranan sumber daya manusia sangatlah penting dikarenakan sumber daya manusia merupakan unsur yang paling menentukan dalam proses pembangunan khususnya sumber daya aparatur yang merupakan mesin penggerak berjalannya roda pemerintahan, pembangunan, dan pelayanan masyarakat, karena itulah manajemen organisasi dituntut untuk selalu proaktif dan dinamis dalam segala hal hal khususnya yang berkaitan dengan pengelolaan sumber daya manusia agar mereka selalu kondisi prima dan berdaya guna dalam melaksanakan suatu pekerjaan untuk mencapai tujuan organisasi. Oleh karena itu untuk meningkatkan kinerja, perlu diperhatikan agar sumber daya manusia dapat bekerja secara efisien dan menampilkan kinerja yang bisa memberi sumbangan terhadap produktifitas merupakan masalah mendasar dari berbagai konsep manajemen dan kepemimpinan.Masjaya (2013).

Kinerja merupakan suatu fungsi kemampuan pekerja dalam menerima tujuan pekerjaan.Dengan definisi tersebut dapat dikatakan bahwa pegawai memegang peranan penting dalam menjalankan segala aktivitas Kantor Kecamatan Penjaringan agar kinerja pegawai dapat tumbuh berkembang tinggi untuk mempertahankan kelangsungan hidup yang ada di Kantor Kecamatan Penjaringan. Menurut Arifin (2012) menyatakan kinerja pegawai merupakan suatu hasil yang dicapai oleh pekerja dalam pekerjaanya menurut kriteria tertentu yang berlaku untuk suatu pekerjaan tertentu.

Kantor Kecamatan Penjaringan merupakan bagian dari pemerintah yang memiliki peranan penting dalam memberi pelayanan kepada masyarakat, namun pada kenyataanya kecamatan penjaringan belum dapat menjalankan fungsi tersebut secara maksimal, pengaruh yang diberikan seorang pemimpin merupakan pengaruh yang secara langsung dapat mensugesti perasaan bawahan untuk mengikuti perintah pimpinan.Diketahui bahwa bawahan cenderung akan mengikuti setiap tindakan pimpinan berdasarkan perilakunya, kondisinya dan situasi kerjanya. Ciri pemimpin tersebut merupakan pemimpin transformasional yang secara eksplisit dimana suatu variabel/instrumen yang akan diuji dalam penelitian ini. Salah satu hal yang bisa menjadi penyebab adanya ketidakjelasan gaya kepemimpinan sehingga dapat berpengaruh kepada lingkungan kerja pegawainya adalah kurangnya perhatian pemimpin terhadap lingkungan sekitar kantor.

Dengan fenomena ini penulis dapat melihat bahwa pemimpin belum ada upaya untuk memberikan teguran kepada pegawai yang melakukan pelanggaran dalam memberikan pelayanan kepada masyarakat.Dan pemimpin disini juga tidak ada upaya untuk memberikan perhatian atau motivasi kepada para pegawainya.Berdasarkan dari hasil penelitian yang dilakukan oleh penulis terhadap beberapa pegawai Kantor Kecamatan Penjaringan terlihat berbagai macam fenomena yang terjadi dalam kaitannya dengan Kepemimpinan Transformasional, Lingkungan Kerja Fisik, dan Stres Kerja.Maka kepemimpinan yang ada di Kantor Kecamatan Penjaringan dapat memegang peranan yang penting untuk mempengaruhi dan menggerakkan bawahan guna mencapai tujuan organisasi secara efektif dan efisien. 
Menurut Yukl (2009) mengatakan bahwa kepemimpinan adalah proses mempengaruhi orang lain untuk memahami apa yang perlu dilakukan oleh kinerja pegawai yang ada di Kantor Kecamatan Penjaringan dan bagaimana tugas itu dilakukan secara efektif, serta proses untuk memfasilitasi upaya individu dan kolektif untuk mencapai tujuan yang ada di Kantor Kecamatan Penjaringan. Jadi, seorang pemimpin atau kepala camat suatu organisasi akan diakui sebagai pemimpin apabila aparat memberikan pengaruh dan mampu mengarahkan bawahannya ke arah tujuan organisasi dan dapat mengambil bagian dalam suatu konteks perubahan alam perubahan yang terus menerus dan tidak menentukan tersebut.

Pada Kantor Kecamatan Penjaringan lingkungan kerja fisik adalah tempat dimana pegawai melakukan aktifitas setiap harinya.Lingkungan kerja yang kondusif memberikan rasa aman dan memungkinkan pegawai untuk dapat bekerja optimal, lingkungan kerja dapat mempengaruhi emosi pegawai. Jika pegawai menyenangi lingkungan kerja dimana dia bekerja, maka pegawai tersebut akan betah di tempat kerjanya melakukan aktivitas sehingga waktu kerja dipergunakan secara efektif. Lingkungan kerja itu mencakup hubungan kerja yang terbentuk antara sesama pegawai dan hubungan kerja antara bawahan dan atasan serta lingkungan fisik tempat pegawai bekerja.

Menurut Panchanatham (2011) berpendapat jika kantor ingin membuat situasi lingkungan kerja yang nyaman, hendaknya lebih memperhatikan penataan ruang kerja seperti penempatan peralatan kerja, penerangan, kebisingan, dan kenyamanan yang nantinya dapat meningkatkan lingkungan kerja yang baik. Lingkungan kerja fisik dalam suatu organisasi sangat penting untuk diperhatikan manajemen, meskipun lingkungan kerja fisik tidak melaksanakan proses produksi dalam suatu pekerjaan, namun lingkungan kerja fisik mempunyai pengaruh langsung terhadap para pegawai yang melaksanakan pekerjaan tersebut di kantor kecamatan.

Pada kantor kecamatan selain kinerja, lingkungan kerja fisik dapat mempengaruhi kinerja pegawai adalah Stres kerja. Stres kerja ialah aspek yang penting bagi Kantor Kecamatan Penjaringan dengan kaitannya dengan kinerja pegawai maka sebab itu aspek stres kerja harus perlu diperhatikan, bahaya stres bisa disebabkan oleh adanya keterlibatan dalam waktu yang lama dengan keadaan yang menuntut secara emosional.Menurut Wirawan (2012) stres merupakan reaksi yang tidak diharapkan muncul sebagai akibat tingginya tuntutan lingkungan kepada seseorang.Sedangkan menurut Timangratuogi (2012) mengungkapkan bahwa stres kerja memiliki hubungan yang negatif signifikan terhadap kinerja pegawai yang ada di Kantor Kecamatan Penjaringan. Tetapi Menurut Robbins (2008) stres adalah suatu kondisi dinamik yang didalamnya seorang individu di konfrontasikan dengan suatu peluang, kendala, atau tuntutan yang dikaitkan dengan apa yang sangat diinginkan dan hasilnya di persepsikan sebagai tidak pasti dan penting.

Berdasarkan beberapa fenomena yang terjadi di Kantor Kecamatan Penjaringan, penyelenggaraan lingkungan kerja fisik sekitar Kantor Kecamatan Penjaringan sangat terganggu dan sangat penting dikaitkan dengan stres kerja karyawan Kantor Kecamatan Penjaringan.Rendahnya lingkungan kerja fisik sangat dipengaruhi oleh perhatian pemimpin terhadap pemberdayaan sumber daya manusia dalam meningkatkan profesionalisme dan kinerja karyawan untuk menyelesaikan pekerjanya menjadi terganggung serta juga untuk meningkatkan kinerja karyawan sangat menurun.

Permasalahan dalam penelitian ini adalah: (1) Apakah Kepemimpinan Transformasional berpengaruh terhadap Kinerja Pegawai pada Kantor Kecamatan Penjaringan?; (2) Apakah Lingkungan Kerja Fisik berpengaruh terhadap Kinerja Pegawai 
pada Kantor Kecamatan Penjaringan?; (3) Apakah Stres Kerja berpengaruh terhadap Kinerja Pegawai pada Kantor Kecamatan Penjaringan?

Tujuan yang ingin dicapai dalam penelitian ini adalah sebagai berikut: (1) Untuk mengetahui pengaruh Kepemimpinan Transformasional terhadap Kinerja Pegawai pada Kantor Kecamatan Penjaringan; (2) Untuk mengetahui pengaruh Lingkungan Kerja Fisik terhadap Kinerja Pegawai pada Kantor Kecamatan Penjaringan; (3) Untuk mengetahui pengaruh Stres Kerja terhadap Kinerja Pegawai pada Kantor Kecamatan Penjaringan.

\section{KAJIAN TEORI}

Pengertian Manajemen Sumber Daya Manusia. Terdapat beberapa pengertian manajemen sumber daya manusia yang telah dikemukan oleh beberapa ahli yaitu sebagai berikut: Menurut Hasibuan (2011), manajemen sumber daya manusia adalah ilmu dan seni dalam mengatur proses hubungan dan proses tenaga kerja agar efektif dan efisien serta membantu terwujudnya tujuan perusahaan, pegawai, dan masyarakat. Menurut Stoner (2013), manajemen sumber daya manusia adalah suatu prosedur yang berkelanjutan yang bertujuan untuk memasok suatu organisasi atau perusahaan dengan orang-orang yang tepat untuk ditempatkan pada posisi dan jabatan yang tepat pada saat organisasi memerlukannya. Sedangkan menurut Dessler (2013), "Human resource management is the process of acquiring, training, relations, health and safety, and fairness concerns". Diartikan bahwa manajemen sumber daya manusia merupakan proses menoleh, melatih, menilai, dan kompensasi karyawan dan memperhatikan hubungan antar karyawan atau tenaga kerja, kesehatan dan keselamatan dan keadilan. Sementara Menurut Sunyoto (2012), manajemen sumber daya manusia adalah sebagai penarikan, seleksi, pengembangan, penggunaan dan pemeliharaan sumber daya manusia oleh organisasi.

Pengertian Kepemimpinan Transformasional. Menurut Suharsono (2012), kepemimpinan transformasional merupakan model yang sekarang banyak diperlukan oleh organisasi, terutama organisasi yang sedang mengalami persoalan yang berat. Menurut Soekarso (2010), pemimpin transformasional (transformasional leaders) adalah sebuah pemimpin yang memberikan pertimbangan dan ransangan intelektual yang diindividukan pada para bawahan dan pengikut. Sementara Bass dan Raihani (2010), kepemimpinan transformasional adalah sebuah proses dimana pemimpin mengambil tindakan untuk meningkatkan kesadaran rekan kerja tentang apa yang benar dan apa yang penting, untuk melampaui minat pribadi mereka demi mencapai kemasalahatan kelompok, organisasi dan masyarakat.

Pengertian Lingkungan Kerja Fisik. Menurut Sedarmayanti (2009) lingkungan kerja fisik adalah semua keadaan berbentuk fisik yang terdapat di sekitar tempat kerja yang dapat mempengaruhi pegawai baik secara langsung maupun secara tidak langsung.Sedangkan lingkungan kerja non fisik adalah semua keadaan yang terjadi berkaitan dengan hubungan kerja, baik hubungan dengan atasan maupun dengan rekan kerja, ataupun hubungan dengan bawahan. Lingkungan kerja dalam suatu kantor perlu diperhatikan, hal ini disebabkan karena lingkungan kerja mempunyai pengaruh langsung terhadap para pegawai. 
Pengertian Stres Kerja. Stres kerja merupakan suatu respon adaptif terhadap suatu situasi yang dirasakan menantang atau mengancam kesehatan seseorang Sopiah (2008).Menurut Rivai dan Deddy (2010) memandang stres kerja sebagai kondisi ketegangan yang timbul karena ketidakmampuan karyawan menghadapi perubahan pada lingkungan pekerjaan.Sedangkan menurut Wirawan (2012) stres merupakan reaksi yang tidak diharapkan muncul sebagai akibat tingginya tuntutan lingkungan kepada seseorang.

Pengertian Kinerja. Menurut Sedarmayanti (2011) mengungkapkan bahwa kinerja merupakan terjemahan dari performance yang berarti hasil kerja seorang pekerja, sebuah proses manajemen atau suatu organisasi secara keseluruhan, dimana hasil kerja tersebut harus dapat ditunjukkan buktinya secara konkrit dan dapat diukur (dibandingkan dengan standar yang telah ditentukan). Menurut Wibowo (2012), kinerja merupakan suatu proses tentang bagaimana pekerjaan berlangsung untuk mencapai hasil kerja. Namun, hasil pekerjaan itu sendiri juga menunjukkan kinerja.Sedangkan menurut Mangkunegara (2013), kinerja karyawan adalah hasil kerja secara kualitas dan kuantitas yang dicapai oleh seseorang karyawan dalam melaksanakan tugasnya sesuai dengan tanggung jawab yang diberikan kepadanya.

Rerangka Pemikiran Hipotesis. Pengaruh Kepemimpinan Transformasional terhadap kinerja pegawai.Kepemimpinan transformasional merupakan pemimpin yang mampu memberikan pengaruh positif dan motivasi yang baik terhadap karyawannya dapat meningkatkan kualitas kinerja pegawai, sebaliknya pimpinan yang tidak mampu memberikan pengaruh positif dan hanya dapat memberikan tekanan pada karyawannya maka dapat mempengaruhi menurunnya kinerja pegawai.Sehingga kepemimpinan transformasional memiliki pengaruh yang cukup besar terhadap kinerja pegawai. Menurut Palgunanto,et al (2010) menemukan bahwa kepemimpinan transformasional berpengaruh positif terhadap kinerja karyawan. Hal ini diperkuat dengan penelitian Tucunan,et al (2014) menemukan bahwa kepemimpinan tranformasional berpengaruh positif terhadap kinerja pegawai.

Pengaruh Lingkungan Kerja Fisik Terhadap Kinerja Pegawai. Hal ini sesuai pernyataan Sedarmayanti (2011) bahwa lingkungan kerja berdampak besar dalam mempengaruhi kinerja pegawai. Perhatian terhadap lingkungan kerja bagi suatu kantor sangatlah penting karena berguna membantu kelancaran jalannya suatu pekerjaan. Lingkungan kerja yang baik dan menyenangkan di sekitar pegawai, maka akan kondusif lingkungan tersebut sehingga membuat pegawai akan merasa nyaman dan tentram, baik dari lingkungan fisik maupun hubungan dengan rekan kerja atau atasan.

Pengaruh Stres Kerja Terhadap Kinerja Pegawai. Stres yang dialami tenaga kerja sebagai hasil atau akibat lain dari proses bekerja, yang dapat berkembang menjadikan tenaga kerja sakit fisik dan mental, sehingga tidak dapat bekerja lagi secara optimal Muhandar (2008). Pernyataan tersebut menunjukkan bahwa apabila stres kerja pegawai meningkat maka akan mempengaruhi kinerja pegawai, pengaruhnya pegawai tidak dapat bekerja dengan baik. 


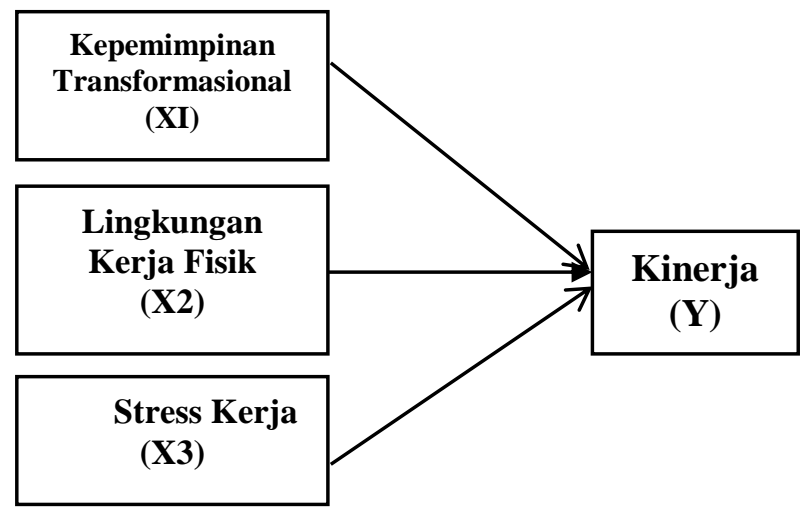

Gambar 1. Rerangka Konseptual

H1 : Kepemimpinan transformasional berpengaruh positif dan signifikan terhadap kinerja pegawai pada kantor kecamatan.

H2 : Lingkungan kerja fisik berpengaruh positif dan signifikan terhadap kinerja pegawai pada kantor kecamatan.

H3 : Stres kerja berpengaruh negatif tetapi tidak signifikan terhadap kinerja pegawai pada kantor kecamatan.

\section{METODE}

Waktu dan Tempat Penelitian.Proses penelitian ini diawali dengan kegiatan mengidentifikasi permasalahan ditempat yang akan digunakan sebagai lokasi penelitian, perumusan masalah yang teridentifikasi, pengumpulan dasar teori yang memperkuat landasan dalam variabel, penyusunan metode dalam pengumpulan data, penyusunan instrument, hingga penentuan teknik pengujian statistik yang dipergunakan. Pada proses ini dibutuhkan waktu penelitian April sampai Mei 2017.

Desain Penelitian. Desain penelitian yang digunakan penulis dalam penelitian ini menggunakan penelitian kausal.Kasual adalah hubungan yang bersifat sebab akibat, jadi terdapat variabel yang mempengaruhi dan variabel yang dipengaruhi Sugiyono, (2013).Penelitian ini merupakan penelitian untuk mengetahui pengaruh tiga variabel independent yaitu, kepemimpinan transformasional, lingkungan kerja fisik dan stres kerja terhadap satu variabel dependen yaitu kinerja pegawai.Dalam hal ini, penelitian bertujuan untuk mengetahuin pengaruh kepemimpinan transformasional, lingkungan kerja fisik dan stres kerja terhadap kinerja pegawai.

Populasi dan Sampel.Menurut Sugiyono (2013), populasi adalah wilayah generalisasi yang terdiri atas obyek atau subyek yang mempunyai kualitas dan karakteristik tertentu yang ditetapkan oleh penelitian untuk dipelajari dan kemudian ditarik kesimpulannya.Populasi penelitian ini adalah Pegawai dan SATPOL PP Kantor Kecamatan Penjaringan Jakarta Utara yang berjumlah 70 pegawai.Menurut Sugiyono (2013), sampel jenuh adalah teknik penentuan sampel apabila semua anggota populasi digunakan sebagai sampel, hal ini sering dilakukan bila jumlah populasi relatif kecil. Istilah lain sampel jenuh adalah sensus, dimana semua anggota populasi dijadikan sampel. Sampel jenuh juga sering diartikan sampel yang sudah maksimum, ditambah berapapun tidak akan merubah keterwakilan. Sehingga penelitian ini menggunakan sampel sebanyak 70 orang responden yang berstatus Pegawai dan SATPOL PP Kantor Kecamatan 
Penjaringan, karena jumlah populasi pegawai dan SATPOL PP pada dua devisi dengan berjumlah 70 orang.

Teknik Pengumpulan Data. Metode pengumpulan data yang digunakan dalam penelitian ini dengan metode pengumpulan data penelitian lapangan (field research) dan penelitian kepustakaan (library research).Penelitian lapangan dilakukan untuk mengetahui kondisi yang terjadi dilapangan secara lebih jelas dan membandingkan dengan teori yang telah didapatkan.Teknik pengumpulan data dalam penelitian ini dengan melakukan survei secara langsung pada obyek penelitian, yaitu pegawai pada Kantor Kecamatan Penjaringan.

Instrumen Pengumpulan Data.Instrumen pengumpulan data yang digunakan adalah kuesioner. Kuesioner merupakan instrument pengumpulan data yang dilakukan dengan cara memberi seperangkat pertanyaan atau pernyataan tertulis kepada responden untuk dijawabnya Sugiyono (2013).

\section{METODE}

Statistik Deskriptif. Statistik deskriptif adalah statistik yang digunakan untuk menganalisis data dengan cara mendiskripsikan atau menggambarkan data yang telah terkumpul sebagaimana adanya tanpa bermaksud membuat kesimpulan yang berlaku untuk umum atau generalisasi Sugiyono (2013).

Uji Kualitas Data.Uji Validitas. Uji validitas bisa dilakukan dengan membandingkan nilai $r$ hitung dengan nilai $r$ tabel untuk degree of freedom $) d f(f)=n-2$, dimana $n$ adalah jumlah sampel penelitian. Jika $r$ hitung $>r$ tabel maka pertanyaan atau indikator tersebut dinyatakan valid, demikian sebaliknya bila $r$ hitung $<r$ tabel maka indikator tersebut dinyatakan tidak valid Ghozali (2013)

Uji Reliabilitas. Perhitungan koefisien reliabilitas baik terhadap seluruh item pada setiap alat ukur maupun terhadap item-item pada setiap aspek. Kesimpulan mengenai tinggi rendahnya reliabilitas aspek maupun alat ukur menggunakan kriteria sebagai berikut Kaplan \& Saccuzo (2012).

1. $0,00-0,19$ : Tidak reliabel

2. $0,20-0,39$ : Kurang reliabel

3. $0,40-0,69$ : Cukup reliabel

4. $0,70-0,89$ : Reliabel

5. $0,90-1,00$ : Sangat Reliabel

Uji Asumsi Klasik. Uji Normalitas. Menurut Imam Ghozali (2007) tujuan dari uji normalitas adalah untuk mengetahui apakah masing-masing variabel residual berdistribusi normal atau tidak. Uji normalitas diperlukan karena untuk melakukan pengujianpengujian variabel lainnya dengan mengasumsikan bahwa nilai residual mengikuti distribusi normal.

Uji Multikolinearitas. Uji Multikolinearitas yaitu pengujian ada atau tidaknya hubungan linear antar variabel bebas.Asumsi model regresi linear berganda mensyaratkan tidakadanya hubungan kombinasi linear antara variabel bebas yang satu dengan yang 
lainnya.Pengujian multikolinearitas dengan menggunakan Variance Influence Factor (VIF), bila nilai VIF kecil dari 10, tidak terdapat multikolinearitas.

Uji Heteroskedastisitas. Uji Heteroskedastisitas yaituyang bertujuan untuk menguji apakah model regresi terjadi ketidaksamaan variance dari residual satu pengamatan ke pengamatan yang lain Ghozali (2011). Cara untuk mengetahui ada tidaknya heteroskedastisitas adalah dengan melihat grafik plot antara nilai prediksi variabel terikat yaitu ZPRED dengan residualnya SRESID. Deteksi ada tidaknya heteroskedastisitas dapat dilakukan dengan melihat ada tidaknya pola tertentu pada grafik scatterplot antara SRESID dan ZPRED dimana sumbu $\mathrm{Y}$ adalah $\mathrm{Y}$ yang telah diprekdisi, dan sumbu $\mathrm{X}$ adalah residual (Y prediksi - Y sesungguhnya) yang telah di studentized.

Uji Analisis Regresi Linear Berganda.Analisi Regresi Linier Berganda digunakan untuk menentukan pengaruh yang ditimbulkan oleh indikator variabel bebas terhadap variabel terikat dengan formulasi sebagai berikut (Sugiyono, 2009)

$Y=a+b_{1} X_{1}+b_{2} X_{2}+b_{3} X_{3}+e$

Dimana : $\mathrm{Y}=$ Kinerja Karyawan; $\mathrm{X}_{1}=$ Kepemimpinan $\quad$ Transformasional; $\quad \mathrm{X}_{2}=$ Lingkungan Kerja Fisik; $\mathrm{X}_{3}=$ Stres Verja; $\mathrm{a}=$ Konstanta; $\mathrm{b}_{1} \mathrm{~b}_{2} \mathrm{~b}_{3}=$ Koefesien Regresi; $\mathrm{e}$ $=$ Eror

Uji Hipótesis. Setelah hipotesis dirumuskan, maka dilakukan suatu pengujian hipotesis untuk mengetahui apakah perubahan dari variabel bebas mempengaruhi variabeltidak bebas.Uji hipotesis terdiri dari uji t dan uji F (ANOVA).Taraf signifikansi yang digunakan dalam pengujian adalah $5 \%$.

Uji Koefisien Determinasi $\left(\mathbf{R}^{2}\right)$. Koefisien determinasi $\left(\mathrm{R}^{2}\right)$ pada dasarnya mengukur seberapa jauh kemampuan model dalam menerangkan variasi variabel dependen.Nilai koefisien determinasi adalah nol dan satu.Nilai $\mathrm{R}^{2}$ yang kecil berarti kemampuan variabelvariabel independen dalam menjelaskan variabel-variabel dependen sangat terbatas.Nilai yang mendekati satu berarti variabel-variabel dependen memberikan hampir semua informasi yang dibutuhkan untuk memprediksi variasi variabel dependen.Kelemahan mendasar penggunaan koefisien determinasi adalah bisa terhadap jumlah variabel independen yang dimasukkan kedalam model.Setiap tambahan satu variabel independen, maka $\mathrm{R}^{2}$ pasti meningkat tidak peduli apakah variabel tersebut berpengaruh secara signifikan terhadap variabel dependen. Oleh karena itu banyak peneliti mengajukan untuk menggunakan nilai Adjusted $R$ square $\left(\mathrm{R}^{2}\right)$ dapat naik atau turun apabila satu variabel independen ditambahkan kedalam model Ghozali (2013).

Uji Signifikan Simultan (t).Uji statistik T menunjukkan seberapa jauh pengaruh satu variabel penjelas/idependent secara individual dalam menerangkan variasi variabel dependen.Apakah variabel indenpenden berpengaruh secara nyata atau tidak Ghozali (2013).

Berdasarkan Tabel 1 dapat diperoleh rumusan persamaan regresi linier berganda untuk variabel independen (kepemimpinan transfornasional, lingkungan kerja fisik dan stres kerja terhadap variabel dependen kinerja pegawai). 


\section{HASIL DAN PEMBAHASAN}

Tabel 1. Analisis Regresi Linear Berganda

\begin{tabular}{|c|c|c|c|c|c|}
\hline \multicolumn{6}{|c|}{ Coefficients $^{\mathrm{a}}$} \\
\hline \multirow[b]{2}{*}{ Model } & \multicolumn{2}{|c|}{ Unstandardized Coefficients } & \multirow{2}{*}{$\begin{array}{c}\begin{array}{c}\text { Standardized } \\
\text { Coefficients }\end{array} \\
\text { Beta }\end{array}$} & \multirow[b]{2}{*}{$\mathrm{t}$} & \multirow[b]{2}{*}{ Sig. } \\
\hline & $\mathrm{B}$ & Std. Error & & & \\
\hline $1 \quad$ (Constant) & 11.610 & 3.732 & & 3.111 & .003 \\
\hline $\begin{array}{l}\text { Kepemimpinan } \\
\text { Transformasional }\end{array}$ & .300 & .069 & .423 & 4.386 & .000 \\
\hline $\begin{array}{l}\text { Lingkungan kerja } \\
\text { fisik }\end{array}$ & .332 & .077 & .419 & 4.325 & .000 \\
\hline Stres kerja & -048 & .056 & -.071 & -.847 & .400 \\
\hline
\end{tabular}

Sumber: Hasil Pengolahan SPSS 23

Tabel 2.Uji Koefisien Determinasi $\left(\mathrm{R}^{2}\right)$

\begin{tabular}{|c|c|c|c|c|}
\hline \multicolumn{5}{|c|}{ Model Summary } \\
\hline Mode & & & Adjusted R & Std. Error of the \\
\hline 1 & $\mathrm{R}$ & R Square & Square & Estimate \\
\hline 1 & $.736^{\mathrm{a}}$ & .542 & .522 & 2.283 \\
\hline
\end{tabular}

Berdasarkan Tabel 2 diketahui hasil koefisien determinasi (adjusted $R^{2}$ ) sebesar 0,522 yang artinya 52,2\% kinerja pegawai dapat dijelaskan oleh variabel kepemimpinan transformasional, lingkungan kerja fisik dan stres kerja. Sedangkan 47,8\% (100\% $52,2 \%$ ) dijelaskan oleh variabel lain yang tidak dimasukkan dalam model penelitian ini.

Berdasarkan hasil uji t diperoleh hasil nilai t sebagai berikut:

a. Koefisien regresi variabel kepemimpinan transformasional memiliki nilai t sebesar 4,386 dengan tingkat signifikansi probabilitas 0,000 lebih kecil dari taraf signifikansi 0,05. Hal ini berarti bahwa variabel kepemimpinan transformasional berpengaruh positif dan signifikan terhadap kinerja pegawai di Kantor Kecamatan Penjaringan Jakarta Utara. Dengan demikian hipotesis kepemimpinan transformasional terhadap kinerja pegawai $\left(\mathrm{H}_{\mathrm{a}} 1\right)$ diterima dan $\left(\mathrm{H}_{0} 1\right)$ ditolak.

b. Koefisien regresi variabel lingkungan kerja fisik memiliki nilai t sebesar 4,325 dengan tingkat signifikansi probabilitas 0,000 lebih kecil dari taraf signifikansi 0,05. Hal ini berarti variabel lingkungan kerja fisik berpengaruh positif dan signifikan terhadap kinerja pegawai di Kantor Kecamatan Penjaringan Jakarta Utara. Dengan demikian hipotesis lingkungan kerja fisik terhadap kinerja pegawai $\left(\mathrm{H}_{2} 2\right)$ diterima dan $\left(\mathrm{H}_{0} 2\right)$ ditolak.

c. Koefisien regresi stres kerja memiliki nilai t sebesar -847 dengan tingkat signifikansi probabilitas 4,00 lebih besar dari taraf signifikansi 0,05. Hal ini berarti variabel stres kerja berpengaruh negatif tapi tidak signifikan terhadap kinerja pegawai di Kantor 
Kecamatan Penjaringan Jakarta Utara. Dengan demikian hipotesis stres kerja terhadap kinerja pegawai $\left(\mathrm{H}_{\mathrm{a}} 3\right)$ ditolak dan $\left(\mathrm{H}_{0} 3\right)$ diterima.

Pengaruh Kepemimpinan Transformasional terhadap Kinerja Pegawai. Berdasarkan hasil pengujian hipotesis pertama perhitungan uji $\mathrm{t}$ menunjukkan hasil nilai $\mathrm{t}$ hitung sebesar 4,386 dan nilai signifikansi sebesar 0,000 dimana nilai lebih kecil dari 0,05. Hasil penelitiannya bahwa koefisien variabel kepemimpinan transformasional $\left(\mathrm{X}_{1}\right)$ memiliki pengaruh positif dan signifikan terhadap kinerja pegawai di Kantor Kecamatan Penjaringan Jakarta Utara maka $\mathrm{H}_{\mathrm{a}} 1$ diterima. Artinya hal ini menunjukkan bila kepemimpinan transformasional yang memiliki oleh pegawai dan SATPOL PP itu baik maka akan meningkatkan dan mempengaruhi kinerja pegawai. Apabila kepemimpinan transformasional di terapkan maka kinerja yang dihasilkan akan lebih baik dan kinerja juga akan meningkat. Hal ini sejalan dengan hasil penelitian dari Marwan Petra Surbakti, Suharnomo (2013), dimana kepemimpinan transformasional berpengaruh positif dan signifikan terhadap kinerja pegawai.

Pengaruh Lingkungan Kerja Fisik terhadap Kinerja Pegawai. Berdasarkan hasil pengujian hipotesis pertama perhitungan uji t menunjukkan hasil nilai t hitung sebesar 4,325 dan nilai signifikansi sebesar 0,000 dimana nilai lebih kecil dari 0,05. Hasil penelitiannya bahwa koefisien variabel lingkungan kerja fisik $\left(\mathrm{X}_{2}\right)$ memiliki pengaruh positif dan signifikan terhadap kinerja pegawai di Kantor Kecamatan Penjaringan Jakarta Utara maka $\mathrm{H}_{\mathrm{a}} 2$ diterima. Artinya hal ini menunjukkan bila lingkungan kerja fisik yang memiliki oleh pegawai dan SATPOL PP itu baik maka akan meningkatkan dan mempengaruhi kinerja pegawai. Apabila Lingkungan kerja fisik di terapkan maka kinerja yang dihasilkan akan lebih baik dan kinerja juga akan meningkat. Hal ini sejalan dengan hasil penelitian dari Vebriana Tri Rahayu (2013), dimana lingkungan kerja fisik berpengaruh positif dan signifikan terhadap kinerja pegawai.

Pengaruh Stres Kerja terhadap Kinerja Pegawai. Berdasarkan hasil pengujian hipotesis ketiga perhitungan uji t menunjukkan hasil nilai t hitung sebesar $-0,847$ dan nilai signifikansi sebesar 0,400 dimana nilai lebih besar dari 0,05. Hasil penelitiannya bahwa koefisien variabel stres kerja $\left(\mathrm{X}_{3}\right)$ memiliki berpengaruh negatif tapi tidak signifikan terhadap kinerja pegawai di Kantor Kecamatan Penjaringan Jakarta Utara maka $\mathrm{H}_{\mathrm{a}} 3$ ditolak. Artinya hal ini disebabkan stres kerja yang diberikan kepada pegawai dan SATPOL PP sudah sangat bagus sehingga bagaimanapun upaya yang dilakukan kinerja dalam peningkatan stres kerja hasilnya akan mempengaruhi kinerja pegawai, maka apabila banyaknya pekerjaan semakin menurun stres kerja akan mengakibatkan kinerja pegawai meningkat. Hal ini sejalan dengan hasil penelitian dari Siti Nurhendar (2007), dimana stres kerja berpengaruh negatif tapi tidak signifikan terhadap kinerja pegawai.

\section{PENUTUP}

Simpulan. Setelah penulis melakukan pengujian hipotesis dan pembahasan mengenai pengaruh kepemimpinan transformasional, lingkungan kerja fisik dan stres kerja terhadap kinerja pegawai pada Kantor Kecamatan Penjaringan Jakarta Utara. Sehingga diperoleh kesimpulan penelitian sebagai berikut:

1. Pengaruh Kepemimpinan Transformasional terhadap Kinerja Pegawai Kantor Kecamatan Penjaringan Jakarta Utara.Berdasarkan uji parsial (Uji t) setelah dilakukan 
analisis membuktikan bahwa pengaruh kepemimpinan transformasional berpengaruh positif dan signifikan terhadap kinerja pegawai pada Kantor Kecamatan Penjaringan Jakarta Utara.

2. Pengaruh Lingkungan Kerja Fisik terhadap Kinerja Pegawai Kantor Kecamatan Penjaringan Jakarta Utara.Berdasarkan uji parsial (Uji t) setelah dilakukan analisis membuktikan bahwa pengaruh lingkungan kerja fisik berpengaruh positif dan signifikan terhadap kinerja pegawai pada Kantor Kecamatan Penjaringan Jakarta Utara.

3. Pengaruh Stres Kerja terhadap Kinerja Pegawai Kantor Kecamatan Penjaringan Jakarta Utara.Berdasarkan uji parsial (Uji t) setelah dilakukan analisis membuktikan bahwa pengaruh stres kerja berpengaruh negatif tapi tidak signifikan terhadap kinerja pegawai pada Kantor Kecamatan Penjaringan Jakarta Utara.

Saran. Berdasarkan hasil penelitian tersebut, maka penulis memberikan beberapa saran yang ingin disampaikan pada pihak-pihak yang bersangkutan guna meningkatkan kepemimpinan transformasional, lingkungan kerja fisik dan stres kerja yang akan berdampak pada kinerja pegawai dan SATPOL PP pada Kantor Kecamatan Penjaringan Jakarta Utara, maka perlumemperhatikan beberapa saran sebagai berikut: Pertama. Bagi perusahaan. Bagi pimpinan Kantor Kecamatan Penjaringan Jakarta Utara disarankan untuk mengevaluasi kembali kepemimpinan transformasional yang diberikan kepada pegawainya. Karena pemimpin berbicara optimis yang berkaitan dengan masa depan untuk mempertahankan pegawai maupun SATPOL PP, maka pemimpin harus lebih optimis agar pegawai maupun SATPOL PP mudah mengerti dan memahami pembicaraan seorang pemimpin.

a. Kantor Kecamatan Penjaringan Jakarta Utara disarankan pegawai maupun SATPOL PP harus mengatur ruangan di tempat kerja untuk mengatasi bau yang tidak sedap. Cara mengatasi bau tidak sedap ruangan tersebut harus tersedia wangi-wangian yang harum, dikarenakan agar tidak dapat mengganggu pekerjaan pegawai maupun SATPOL PP.

b. Bagi pimpinan Kantor Kecamatan Jakarta Utara di sarankan untuk menyesuaikan batas waktu pekerjaan dengan stres kerja yang diberikan kepada pegawai maupun SATPOL PP, karena merasa pekerjaan yang diberikan cukup dilihat dari hasil jawaban responden stres kerja. Agar pegawai dan SATPOL PP dapat menyelesaikan pekerjaan yang selalu kejar target untuk diselesaikan. Maka mengerjakan pekerjaanya yang baik perlu atasan memberikan waktu yang cukup bagi pegawai dan SATPOL PP sehingga dapat menyelesaikan tugas merasa tenang dan tidak terburuburu, dan akan maksimal karena telah diberikan waktu yang cukup untuk menyelesaikan pekerjaan.

Kedua. Bagi Peneliti Selanjutnya. Penulis menyarankan bahwa untuk penelitian lebih lanjut sebaiknya mengadakan pengembangan penelitian ini dengan menambah variabel selain kepemimpinan transformasional, lingkungan kerja fisik dan stres kerja untuk mempengaruhi kinerja pegawai.Hal ini karena masih banyak variabel-variabel yang belum ditemukan penulis yang masih memiliki hubungan dengan kepemimpinan transformasional, lingkungan kerja fisik dan stres kerja yang dapat mempengaruhi kinerja pegawai. 


\section{DAFTAR RUJUKAN}

A.A Ayu. Sriathi.(2015). "Pengaruh Kepemimpinan Transformasional, Lingkungabn Kerja Fisik Dan Kompensasi Terhadap Kinerja Karyawan”. Jurnal Manajemen Unud, 4 (7), 1771-1784.

Al Fajar, Siti dan Heru, Tri. (2010). Manajemen Sumber Daya ManusiaYogyakarta: UPP STIM YKPN.

Baskoro, C.A. (2014). "Pengaruh Kepemimpinan Transformasional, Motivasi, Dan Disiplin Kerja Terhadap Kinerja Karyawan”. Management Analysis Journal, 3 (2), $1-2$.

Choudhary, A.I and Syed Azeem Akhtar. (2014). "Impact of Transformasional and Servent Leadership on Organizational Performance: A Comparative Analysis". Journal Springer Science \& Business, 116 (443), 120-135.

Dessler, Gary. (2013). Manajemen Sumber Daya ManusiaJakarta : Indeks.

Dewi, Chadek Novi Charisma., I Wayan Bagia, dan Gede Putu Agus Jana Susila (2014)."Pengaruh Stres Kerja dan Kepuasan Kerja Terhadap Kinerja Kryawan pada bagian tenaga penjualan UD Surya Raditya Negara”, Jurnal Manajemen, 2.

Firda.(2015). "Pengaruh Gaya Kepemimpinan Transformasional dan Disiplin Kerja terhadap kinerja karyawan pada Hotel Grand Victoria di Samarinda".Jurnal Ilmu Administrasi, 3 (3), 612-624.

Gadot, Eran Vigoda.(2015). "Leadrship style, Organizational Politics, and Employees Performance". Journal Emerald Group Publishing Limited, 36(5), 661-683.

Hasibuan, Malayu S.P. (2012). Manajemen Sumber Daya Manusia. Jakarta Bumi Aksara.

Ivancevich, Jhon M, Robert, Michael T, Matteson. (2006). Perilaku dan Manajemen Organisasi.Penerbit: Airlangga.

Kaplan, M \& Dennis P. Saccuzzo (2012).Psychological Testing: Principles, Application, \& Issues, $8^{\text {th }}$ Edition. Cengage Learning .

Karihe, John Ng'ang'a., Professor G.S. Namusongo and Dr. Mike Iravo.(2015). "Effect of Working Facilities Stres Factors on the Performance of Employees in Public Universitas in Kenya", International Journal of Scientific and Research Publications, 5 (5)Fromhttp://www.ijsrp.org/research-paper-0515.php?rp=P414103 on April, 202016.

Kaswan.(2012). MSDM untuk Keunggulan Bersaing Organisasi. Yogyakarta: Graha Ilmu. Luthans, F (2006). Perilaku Organisasi. Terjemahan Vivin Andhika dkk. (2012). Yogyakarta: Penerbit Asli.

Mahendra,K.M.O, Mujiati Ni Wayan (2015). "Pengaruh Gaya Kepemimpinan Transformasional, Disiplin Kerja dan Burnout pada Kinerja Karyawan Arma Museum And Resort". Jurnal Manajemen Unud Ilmu Administrasi. 2 (10), 31723197.

Mangkunegara, A.A. Anwar Prabu. (2013). Manajemen Sumber Daya Manusia.Perusahaan. Bandung: PT. Remaja Rosdakarya Offiset.

Mangkunegara.(2011). Evaluasi Kinerja SDM. Bandung: PT Rafika Naitama Rivai, Veithzal. (2011). Manajemen SDM Untuk Perusahaan Dari Teori Ke Praktek. Jakarta: Raja Grafindo Persada.

Masjaya.(2013). "Pengaruh Lingkungan Kerja dan Motivasi Kerja Terhadap Prestasi Kerja Pegawai di Kemacatan Tenggarong Kabupaten Kutai Kartanegara”.Jurnal Pemerintahan Integratiff. 1 (1), 12-25. 
Raihani.(2010). "Kepemimpinan Transformasional". Yogyakarta: LKIS Printing Cemerlang.

Reitz. H. J. (2010). Organizational Behaviour: Management. Homewood III: R D.Irwan.

Rivai, Veithzal dan Sagala, Ella Jauvani.(2011). Manajemen SDM Dalam Organisasi Publik dan Bisnis.Bandung: Alfabeta.

Robbins, S.P, \& Judge, T.A (2008). Perilaku Organisasi, Edisi Kedua Belas Jakarta: Salemba Empat.

Samad, Sarmina. (2015). "The Influence of Innovation and Transformasional Leadership on Organizational Performance". Procedia - Social and Behavioral Sciences Journal, 57 (486), 312-336.

Sanusi, Anwar. (2011). Metodologi Penelitian Bisnis.Jakarta. Salemba Empat.

Sashkin, Marshall, Molly G.Sashkin. (2011). Prinsip Kepemimpinan. Jakarta: Erlangga.

Shabab, Mohamad Ali and Inna Nisa. (2014). "The Influence of Leadership and Work Attitudes toward Job Satisfaction and Performance of Employee", International Journal Of Managerial Studiess and Research (IJMSR), 43 (2), 69-77.

Soekarso, Agus Sostro, Iskandar Putong, Cecep Hidayat. (2010). Teori Kepemimpinan.Jakarta: Mitra Wacana Media.

Sugiyono, (2013). Metode Penelitian Manajemen. Alfabeta. Bandung.

Suharsono. (2012). Pengetahuan dasar Organisasi (Konsep-Konsep Dasar, Teori, Struktur, dan Prilaku).Jakarta: Universitas Atmajaya.

Suyatminah.(2013). Jurnal Bimbingan dan Konseling "PSIKOPEDAGOGIA”, 2 (2), 323 331. 